\title{
Michèle M. Magill, Katherine S. Stephenson, Dits de femmes. Entretiens d'écrivaines françaises
}

\section{Elisa Bricco}

\section{Q OpenEdition}

1 Journals

\section{Edizione digitale}

URL: https://journals.openedition.org/studifrancesi/38336

DOI: 10.4000/studifrancesi.38336

ISSN: 2421-5856

\section{Editore}

Rosenberg \& Sellier

\section{Edizione cartacea}

Data di pubblicazione: 15 décembre 2004

Paginazione: 651-652

ISSN: 0039-2944

\section{Notizia bibliografica digitale}

Elisa Bricco, «Michèle M. Magill, Katherine S. Stephenson, Dits de femmes. Entretiens d'écrivaines

françaises», Studi Francesi [Online], 144 (XLVIII | III) | 2004, online dal 30 novembre 2015, consultato il 08 mai 2021. URL: http://journals.openedition.org/studifrancesi/38336 ; DOI: https://doi.org/10.4000/ studifrancesi.38336

Questo documento è stato generato automaticamente il 8 mai 2021.

\section{(c) $(1) \ominus$}

Studi Francesi è distribuita con Licenza Creative Commons Attribuzione - Non commerciale - Non opere derivate 4.0 Internazionale. 


\title{
Michèle M. Magill, Katherine S. Stephenson, Dits de femmes. Entretiens d'écrivaines françaises
}

\author{
Elisa Bricco
}

\section{NOTIZIA}

MICHÈLE M. MAGILL, KATHERINE S. STEPHENSON, Dits de femmes. Entretiens d'écrivaines françaises, Birmingham, Alabama, Summa Publications, 2003, 197p.

1 Dieci scrittrici contemporanee si raccontano in prima persona in questo volume che raccoglie le interviste a Marie Chaix, Andrée Chedid, Geneviève Dormann, Annie Ernaux, Sylvie Germain, Benoîte Groult, Jeanne Hyvrard, Michèle Manceaux, Michèle Perrein. La parola detta si aggiunge così alla parola scritta e letta nelle opere delle autrici, fornendo al lettore e allo studioso un complemento per la conoscenza delle scrittrici, del loro lavoro, e soprattutto della loro posizione nel mondo delle lettere.

2 E, proprio il rapporto delle dieci écrivaines con l'ambiente letterario e la critica costituisce il principale interesse delle curatrici del volume: nella prefazione viene infatti messo l'accento sulla difficile posizione della femme écrivain in Francia, perché la critica stenta a riconoscerla, ad ammetterne le qualità e a considerarla auteure.

3 L'interesse maggiore del volume riposa comunque nella parola delle scrittrici che si mettono a nudo esponendo la loro passione per la scrittura, raccontando il loro divenire scrittrici e il loro rapporto con la parola scritta.

Ogni intervista è accompagnata inoltre da una nota bio-bibliografica e da una bibliografia critica. 